\title{
THE ROLE OF MUHAMMADIYAH ISLAMIC MOVEMENT IN HACKING A NEW MAP OF LOCAL CULTURE IN INDONESIA
}

\author{
Riska Aprilianti ${ }^{1 *}$, Dayang Safira Bella Avilia ${ }^{2}$, Romelah $^{3}$ \\ ${ }^{1 *}$ Konfederasi Serikat Pekerja Seluruh Indonesia (KSPSI), Paser Regency, East Borneo, Indonesia, \\ Indonesia, riskaaprilianti22@gmail.com (corresponding). \\ ${ }^{2,3}$ Magister Ilmu Hukum, Universitas Muhammadiyah Malang, Indonesia.
}

\begin{abstract}
This article aims to examine the movement of Muhammadiyah. Muhammadiyah's commitments since its establishment until now is that Muhammadiyah has positioned itself as a pure creed-based Islamic da'wah movement. Muhammadiyah's role in creating a local culture for modern culture, Muhammadiyah has several programs launched in the field of culture. To examine those backgrounds, this article uses a historical approach to the normative juridical method. This article found that Muhammadiyah's program in the field of culture is an effort intended to develop an appreciation of art that is in line with the views of Muhammadiyah's beliefs. One of the applications of Muhammadiyah's cultural program is the development of culture-based education. Muhammadiyah is expected to be able to carry out its strategic role in terms of culture very optimally. In forming a progressive culture, Muhammadiyah does not only need a commensurate movement strategy but at the same time has a building of thought that goes beyond, so that it appears as a carrier of a progressive alternative Islamic message with a strong and superior character. From the womb of Muhammadiyah was born the transformation of Indonesian culture which is religious and progresses parallel to and even superior to other nations. Here the important role of actualizing the view of progressive Islam as declared in the One Century Congress, which is accompanied by the strategy of the enlightenment movement (a movement that liberates, empowers, and advances) in all its orientations and steps.
\end{abstract}

Keywords: Muhammadiyah; Culture; Modern; Progress

\section{INTRODUCTION}

Muhammadiyah is one of the oldest and largest Islamic organizations in Indonesia that cannot avoid the demands of change due to globalization. Muhmammadiyah is an Islamic movement that formally mentions the existence of the ma'ruf nahi munkar charity movement. But also Muhammadiyah can be dubbed with various identities such as Modernist Islam, Moderate Islam, Pure Islam and Advanced Islam (Anis, 2019). Muhammadiyah movement also has a very large contribution to the development of Islam in Indonesia. Muhammadiyah is an Islamic organization or movement founded by Kiai Ahmad Dahlan in Yogyakarta on November 18, 1912 (Huda \& Kusumawati, 2019).

The establishment of this organization coincided with the proliferation of religious and nationalist organizations throughout Indonesia among these religious organizations are SDI 
(Sarekat Dagang Islam -1909) which many people from the Sufi movement included in, SI (Islamic Union-1912), and Jami'yyat Khair (1905) and others. The basis of the struggle is Islam and Indonesian nationality. The nature of Muhammadiyah organization is engaged in the field of religion, education, and socio-culture that leads to the achievement of birth and inner happiness (Rusydi, 2016).

The history of muhammadiyah birth is based at least on two factors, namely subjective factors and objective factors. Subjective factors that are very strong, can even be said to be the main determinant factor that encourages the establishment of Muhammadiyah is the result of the deepening of K.H. Ahmad Dahlan towards the Qur'an both in terms of reading and studying, discussing and reviewing the content of its contents. While the Objective factor is due, among others: first, the impurity of Islamic practices due to the non-making of the Qur'an and Sunnah as the only reference by most Indonesian Muslims. Second, educational institutions owned by Muslims have not been able to prepare a generation that is ready to carry out the mission as "Caliph of Allah on earth". Pondok pesantren is one of the typical educational institutions owned by Indonesian Muslims. As well as a typical education in Indonesia (Zarro, Yunani, \& Dhita, 2020).

Muhammadiyah as a religious organization develops conceptualizations about culture. At the 43rd Conference and National Conference (Munas) Tarjih XXIII in Aceh, in 1995. Although it was not decided in writing, implicit cultural discourse began to develop. One of them is a paper delivered by Kuntowijoyo entitled Culture, Advanced Industrial Society and Da'wah, which explains that culture is human nature. This paper is a criticism of muhammadiyah religious patterns that are considered dry because they are too rational and puritanical to forget the emotional aspects and traditions of lokal culture (Burhani, 2006).

One of the problems we face in the efforts to build bangs akita is mental development (Masbullah, 2018). What is meant in this case is an effort to increase the ability of rokhaniah to live all aspects of life and the procedures that occur in society with the aim of achieving the greatest happiness of life, one way to carry it out is the appreciation of art (Khomaeny, 2018). Art provides a deep understanding of people and provides interaction and assessment of events in life. Umar Kayyam, argued that art can be seen as a way for humans to reimagine life through various imaginations in the friendliest way. So in this case there are many efforts in order to improve the ability of rokhaniah to live all aspects of life and values in the community is the development of the ability to carry out cultural appreciation, namely creating a modern culture and forward in harmony with muhammadiyah views and beliefs (Luthfi \& Mq, 2019). In this paper, the author wants to discuss the "Role of Muhammadiyah Islamic Movement in Hacking New Maps of Local Culture in Indonesia to Create a Modern and Advanced Culture".

\section{METHODOLOGY}

This research is based on a literature study (library research), which is a study whose object of study uses library data in the form of books as a source of data (Widyakso \& Wiryani, 2021) (Zain, Wiryani, \& Hasanah, 2021). this research is done by reading, studying, and analyzing from various existing fields in the form of textbooks, documents, journals, magazines and other sources related to the problems in this article (Zain et al., 2021) (Harahap, 2014).

\section{RESULTS AND DISCUSSION}




\section{Muhammadiyah as Central Movement}

Muhammadiyah is one of the Islamic unions engaged in da'wah, education, social, and also religion that is very active in broadcasting Islam through education (Ali, 2016), including madrassas and schools to increase public knowledge. One of Muhammadiyah's commitments since its establishment until now is that Muhammadiyah positions itself as a pure faith-based Islamic da'wah movement. So the main basis that later becomes khittahnya is tand if al-Aqidah or purification of the creed.

This basic commitment is also a major character in the development of religious thought that he did. Muhammadiyah as a movement, in following the development and change, always has an interest to implement amar ma'ruf nahi-munkar, and organize movements and charitable businesses that are in accordance with the field chosen is the community, as Muhammadiyah's efforts to achieve its goal: upholding and upholding the Religion of Islam so that the realization of the main, fair and prosperous society that is headed by Allah SWT.

In carrying out these efforts, Muhammadiyah runs on the principle of its movement, as referred to in the Matan Belief in Muhammadiyah Life Ideals. Muhammadiyah's beliefs and ideals have always been the foundation of the Muhammadiyah movement, as well as for the movement and charitable enterprises and their relationship to people's lives and statehood, as well as in cooperation with other Islamic groups. The rapid development of a culture is characterized by the consistency of developers including Muhammadiyah to practice the teachings it believes in. Muhamadiyah as a cultural movement is proclaiming the importance of cultural implementation through cultural da'wah.

The concept of Muhammadiyah da'wah is more open, and the cultural heritage of the past, which has not been allowed to be revoked, is preserved as a characteristic of the nation's culture. The study of culture is done through two dimensions, namely the critical-appreciative dimension (melting into the ritual tradition) and the critical dimension (making corrections). According to Munir Mulkhan, the concept of the tajdid movement, is as a rational effort in the interpretation, practice and realization of Islamic teachings by sticking to the Qur'an and al-Sunnah. Thus, Muhammadiyah preaches by melting in the culture of the community. In kuntowijoyo language, the process of melting with culture is preceded by a process of being accredited (Sumadi, 2018).

\section{The Role of Muhammadiyah in Hacking Local Culture in Indonesia}

There are many cases of local culture in some regions often mixing Islamic values with beliefs in animism and dynamism that are contrary to the values of Tawhid. Muhammadiyah's role as an Islamic movement has a responsibility to provide understanding in a polite and professional way (Sulistya, 2020).

Muhammadiyah's role in hacking local culture is to make local culture as a medium for preaching. Cultural da'wah is a form of accommodation to the local culture. Cultural da'wah will make local culture as a proselytizing media of muhammadiyah organizations. Muhammadiyah's cultural strategy in cultural da'wah is important for the development of association. Since the beginning of Muhammadiyah is a cultural movement that sows da'wah with wisdom. Muhammadiyah is a cultural movement that is friendly to local culture. Ijtihad Muhammadiyah is affirming the spirit of da'wah to accommodate local culture.

The establishment of universities conducted by Muhammadiyah in the 1980s is the first step in building an egalitarian and elegant Islamic civilization and culture in Indonesia. Scholars and 
educated people in Muhammadiyah College (PTM) are encouraged to disseminate their thoughts. by writing books and writing articles in various journals, local, national and international baik. This is based on the main characteristic of an advanced culture and civilization is its sophistication in all its patterns and manifestations, including the sophistication of thinking. The advanced and sophisticated thinking of a nation poured and recorded in the form of books published of all kinds will clearly describe the level of development of the progress of a nation's culture and civilization. In addition, the books produced must also be stored well in the library and easy to read (accessed by various circles) for the benefit of science. Muhammadiyah organization is also expected to start thinking about a "library" that is representative for the progress of an Islamic culture in Indonesia. They must also have a good publisher and printing press for the resulting works to be disseminated. The more scholars and scholars produced by Muhammadiyah University, the faster it will also develop culture and civilization in Indonesia. In addition, every Muhammadiyah University internally must always improve its educational administration and management system. Good management will be done if a college has capable and responsible professionals and managerial personnel (Wardana, 2017).

Muhammadiyah's role in creating a local culture for a modern culture, Muhammadiyah has several programs launched in the field of culture. Muhammadiyah program in the field of culture is an effort intended to develop an appreciation of art that is in harmony with muhammadiyah belief views. Muhammadiyah cultural program is applied one of them to the development of education based on culture (Al-Fatih, 2021). Muhammadiyah is expected to carry out its strategic role in terms of culture very optimally.

Some criticism of the Muhammadiyah movement at the level of implementation, because this movement tends to be anti-cultural, not as mandated by the values in the organization's decisions. Munir Mulkhan's research on the farming community in Wuluhan Subdistrict, Jember, East Java, shows that Muhammadiyah does not yet have a precise concept in an effort to encourage change and progress of society with popular culture. This research resulted in the typology of Muhammadiyah followers into four variants: Al-Ikhlas, Kyai Dahlan, Munu (MuhammadiyahNU), and Marmud (MarhenisMuhammadiyah). Al-Ikhlas variant is a very puritanical minority group and denounces the practice of tuberculosis (Superstition, Heresy, and Khurafat). Although highly respected for its piety, al-Ikhlas group was never able to occupy an important position in the organization of subdistrict (branch) and village (twig) level. While the Kyai Dahlan variant belongs to a minority group but controls leadership in branches and branches. This is because kyai Dahlan group is very tolerant of tb practices even though they do not participate. Another minority group is Marmud who still make tuberculosis a tradition. While the majority group in Muhammadiyah followers in Wuluhan is Munu who works as a farmer and still makes tuberculosis as a tradition.

This finding clearly shows that popular culture that Muhammadiyah has long opposed through da'wah against tuberculosis is still attached to some Muhammadiyah followers, especially those in rural areas. The statement that Muhammadiyah is an anti-cultural movement is not enough just to look at its appreciation of popular culture. Because, according to taylor's definition, culture in general is as a whole complexity that includes knowledge, beliefs, art, moral values, laws, social traditions, and all abilities and habits acquired by humans in their position as members of society (culture or civilization taken in its with ethno graphic sense, is that complex whole which includes 
knowledge, belief, art, morals, law, custom, and any other capabilities and habits acquired by man as a member of society).( David L. Shills, 1996) This understanding illustrates how broad the scope of culture is. Therefore, it is very inappropriate to say muhammadiyah is an anti-cultural movement. Kuntowijoyo termed Muhammadiyah is a new cultural movement without the old culture (Naibei, 2014).

As a consequence of the formulation of the methodological framework of dialecticals of local religions and cultures, Muhammadiyah initiated two important things. First, the autonomy and decentralization of religious thought in the context of local culture. Second, open the widest space to accommodate the plurality of religious thought. This is a new step - not to say revolution - a giant organizational convention that is usually centralistically managed. In relation to local culture, Muhammadiyah implements a policy of decentralization of discourse and fatwas in the institutional hierarchy of the organization. That is, the plurality of local culture cannot be answered by top down-looking religious thinking and instructions of the Tarjih Assembly and the Development of Islamic Thought at the central level. Because, cultural diversity itself is a real problem faced at the local level. With this policy, it is possible to be born plural religious discourses and fatwas according to the dialectic of space and time, which in turn can enrich the treasures of local Islamic thought that are varied, creative, and innovative (Octalia, 2019).

Decentralization requires Muhammadiyah to immediately reduce its centralistic management. In addition to decentralization, Muhammadiyah must also open wide space for diversity of thought. The reason, the greatness and abundance of human resources in Muhammadiyah continues on the diversity of religious thought. There are at least three dominant schools of thought in these urban community-based organizations. First, the current of rationalistic religious thought. Second, the flow of religious thought is spiritual/ mystical. This discourse of spirituality is driven by young activists. In fact, the Sufi movement / spirituality is now venturing into a practical state as it happens on Muhammadiyah campuses. Third, in addition to the two currents, the religious attitude of formalism-skriptural is also increasingly widespread among muhammadiyah citizens. This symptom is a reaction to "theological routineization" (Mursalin, 2018).

Muhammadiyah in the modern era is very fast in its development, but besides that muhammadiyah also still appreciates lolal cultures that are still embraced by culture in Indonesia. The development of technology and information greatly influences the development of muhammadiyah in the modern era, one of which is with da'wah programs through the media and published by the media is a surefire way to spread the teachings of Islam in the modern era. Muhammadiyah is not anti with karena culture is basically muhammadiyah itself has a very close and dynamic relationship with local culture. At the beginning of the establishment of Muhammadiyah and culture as a single identity, Muhammadiyah greatly appreciated the javanese culture of gerebek in Yogyakarta. Gerebek is a hereditary culture of the people of Yogyakarta which is held three times every year including, gerebek mulud, large raid and gerebek pasa. Muhammadiyah here considers that raids can also be used in the spread of da'wah in Yogyakarta. Muhammadiyah is not only a faith-based organization, but also muhammadiyah provides polyclinics, hospitals, educational facilities and many more. In the field of social health muhammadiyah provides sembako assistance to non-Muslims, accepts coexistence with other people and appreciates the beliefs of other people (Kahfi, 2020). 
Muhammadiyah movement is known as a modern movement that makes changes in the field of culture. Muhammadiyah movement model with its initial ideal is renewal (modernization). Modernization (tajdid) is a movement of muhammadiyah thinking reform to find solutions to various problems. Muhammadiyah Islamic Movement In Hacking a New Map of Local Culture in Indonesia To Create a Modern and Advanced Culture is shown through Muhammadiyah's attitude in the early era to the growth and development of today many inspired traditions of modern nations that are present along with the entry of colonialism. In hacking culture to create a modern and advanced culture, the presence of figures and historians has a central role in muhammadiyah organization to explore the basic values of Muhammadiyah and make it into a pattern of movement of systematic and dynamic development, especially in its involvement in creating a modern and advanced culture.

In forming a sustainable culture, Muhammadiyah not only needs a commensurate movement strategy but at the same time has an up-and-coming thought, thus appearing as a progressive alternative Islamic messenger with a strong and superior character. From the womb of Muhammadiyah was born the transformation of Indonesian culture that is religious and advanced parallel and even superior to other nations. Here the important role of actualizing the advanced view of Islam as proclaimed in the One Century Conference, which is accompanied by the strategy of the enlightenment movement (the movement that liberates, empowers, and advances) in all its orientations and steps. The Islamic view that Muhammadiyah believes, understands, and practice is very basic, broad, and comprehensive that requires an actualization process in this Islamic movement system. The actualization process to realize Islam that continues requires transformative earthing, namely smarter and sharper actuality in making changes that are reforming as kyai Dahlan's courage a hundred years ago in the figure of the Lightener. With its weaknesses and strengths, Muhammadiyah in the span of one hundred years has given a pattern to the culture of indonesian people and people who have progress, namely becoming more rational, modern, miderat, shaleh individually and socially, charitable-oriented, and islamic character. The burdens and challenges of creating a strong Islam to build a society with an enlightened culture and civilization are returned to the commitment and earnestness of muhammadiyah members, cadres, and leaders massively. If not, then Islam that continues to build the main culture and civilization is like a puddle of lakes, which are beautiful to the eye and used as a tourist center that pleases for a moment; But it does not give birth to an enlightening movement of change: liberating, empowering, and advancing life (Burhani, 2019).

\section{CONCLUSION}

Based on the description of the discussion above, it can be concluded that Muhammadiyah preaches by melting in the culture of the community. Muhammadiyah's role in creating a local culture for a modern culture, Muhammadiyah has several programs launched in the field of culture. Muhammadiyah program in the field of culture is an effort intended to develop an appreciation of art that is in harmony with muhammadiyah belief views. Muhammadiyah cultural program is applied one of them to the development of education based on culture. Muhammadiyah is expected to carry out its strategic role in terms of culture very optimally. In forming a sustainable culture, Muhammadiyah not only needs a commensurate movement strategy but at the same time has an up-and-coming thought, thus appearing as a progressive alternative Islamic messenger with a 
strong and superior character. From the womb of Muhammadiyah was born the transformation of Indonesian culture that is religious and advanced parallel and even superior to other nations. Here the important role of actualizing the advanced view of Islam as proclaimed in the One Century Conference, which is accompanied by the strategy of the enlightenment movement (the movement that liberates, empowers, and advances) in all its orientations and steps.

\section{REFERENCES}

Al-Fatih, S. (2021). House of Role as an Effort to Protect Children From Violence: An Indonesian Perspective. Audito Comparative Law Journal, 2(1), 1-10. https://doi.org/10.22219/aclj.v2i1.15145

Ali, M. (2016). Membedah Tujuan Pendidikan Muhammadiyah. Profetika Jurnal Studi Islam, 17(1), 43-56. https://doi.org/10.23917/profetika.v17i01.2099

Anis, A. (2019). Muhammadiyah Dalam Penyebaran Islam. Jurnal Mimbar, 5(2), 65-80. https://doi.org/10.47435/mimbar.v1i1.279

Burhani, A. N. (2006). The Ideological Shift of Muhammadiyah From Cultural Into Puritanical Tendency in 1930s. Jurnal Masyarakat Dan Budaya, 8(1), 1-22. https://doi.org/10.14203/jmb.v8i1.178

Burhani, A. N. (2019). Untuk Islam Berkemajuan. Maarif Arus Pemikiran Islam Dan Sosial, 14(2), 75-84. https://doi.org/10.47651/mrf.v14i2.63

Harahap, N. (2014). Penelitian Kepustakaan. Iqra', 8(1), 68-73. Retrieved from http://dx.doi.org/10.30829/iqra.v8i1.65

Huda, S., \& Kusumawati, D. (2019). Muhammadiyah Sebagai Gerakan Pendidikan. Tarlim Jurnal Pendidikan Agama Islam, 2(2), 163-173. https://doi.org/10.32528/tarlim.v2i2.2607

Kahfi, M. (2020). Peranan Muhammadiyah Sebagai Gerakan Islam Berkemajuan di Era Modern. Al-Risalah Jurnal Studi Agama Dan Pemikiran Islam, 11(2), 110-128. https://doi.org/10.34005/alrisalah.v11i2.590

Khomaeny, E. F. F. (2018). Seni dan Budaya dalam Perspektif Muhammadiyah. Magelaran: Jurnal Pendidikan Seni, 1(1), 35-50. https://doi.org/10.35568/magelaran.v1i1.246

Luthfi, F., \& Mq, W. L. (2019). Sinergitas Nahdlatul Ulama dan Muhammadiyah dalam Pengembangan Ekonomi Islam di Indonesia. Al-Urban: Jurnal Ekonomi Syariah Dan Filantropi Islam, 3(2), 137-148. https://doi.org/10.22236/alurban_vol3/is2pp137-148

Masbullah. (2018). Konflik dan Integrasi Muhammadiyah dengan Budaya Lokal di Lombok Timur. Journal Ilmiah Rinjani, 6(2), 240-255. https://doi.org/10.12345/jir.v6i2

Mursalin, S. (2018). Akomodasi Budaya Lokal Dalam Putusan Tarjih Muhammadiyah. MIZANI:Wacana Hukum, Ekonomi Dan Keagamaan, 5(2), 159-166. Retrieved from http://dx.doi.org/10.29300/mzn.v5i2.1444

Naibei, P. (2014). Culture and Sustainable Development. Culture and Sustainable Developmemnt, 1. https://doi.org/10.13140/2.1.2692.9928

Octalia, E. (2019). Dakwah Kultural: Relasi Islam dan Budaya Lokal. Ath-Thariq Jurnal Dakwah Dan Komunikasi, 3(2), 179-192. https://doi.org/10.32332/ath_thariq.v3i2.1548 
Rusydi, R. (2016). Peran Muhammadiyah (Konsep Pendidikan, Usaha-Usaha di Bidang Pendidikan, dan Tokoh). Tarbawi Jurnal Pendidikan Agama Islam, 1(2), 139-148. https://doi.org/10.26618/jtw.v1i2.367

Sulistya, A. Q. P. (2020). Protection Of The Civilian Population As The Implementation Of The Principle Of Discrimination. Audito Comparative Law Journal (ACLJ), 1(2), 94-104. Retrieved from https://doi.org/10.22219/audito.v1i2.13753

Sumadi, E. (2018). Pendidikan Islam Dalam Perprektif Ilmunya Kuntowijoyo. Hikmatuna Journal For Integrative Islamic Studies, 4(2), 149-165. https://doi.org/10.28918/hikmatuna.v4i2.1274

Wardana, A. (2017). Peran Muhammadiyah Dalam Meretas Peta Baru Kebudayaan Islam Di Indonesia. Dinamika UMT, 2(2), 78-88. Retrieved from http://dx.doi.org/10.31000/dinamika.v2i2.1439

Widyakso, R., \& Wiryani, F. (2021). Analisis Pelaksanaan Putusan Peradilan Agama Terhadap Nafkah Perceraian Dalam Perspektif Hukum Nasional dan Hukum Islam Bagi PNS. Audito Comparative Law Journal (ACLJ), 2(2), 86-109. https://doi.org/10.22219/aclj

Zain, H. A., Wiryani, F., \& Hasanah, I. (2021). Kesadaran Hukum Sertifikasi Halal Pelaku Usaha Rumah Makan di Kota Malang. Indonesian Law Reform Journal, 1(1), 122-142. https://doi.org/10.22219/ilrej.v1i1.16130

Zarro, M., Yunani, Y., \& Dhita, A. N. (2020). Muhammadiyah Sebagai Gerakan Islam dan Pendidikan. Factum Jurnal Sejarah Dan Pendidikan Sejarah, 9(1), 61-66. https://doi.org/10.17509/factum.v9i1.21503 